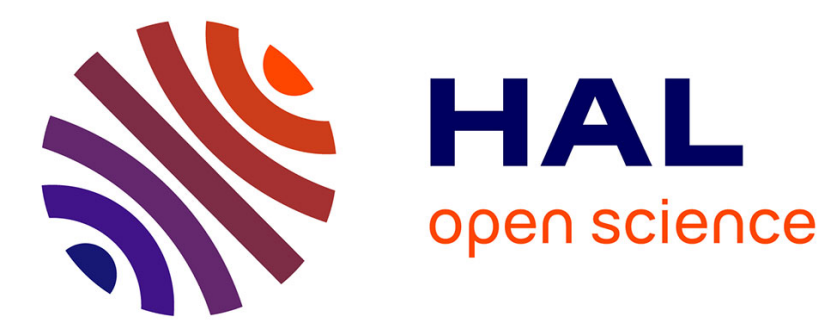

\title{
Nest management increases pollinator density in passion fruit orchards
}

Camila Junqueira, Marcela Yamamoto, Paulo Oliveira, Katja Hogendoorn, Solange Augusto

\section{- To cite this version:}

Camila Junqueira, Marcela Yamamoto, Paulo Oliveira, Katja Hogendoorn, Solange Augusto. Nest management increases pollinator density in passion fruit orchards. Apidologie, 2013, 44 (6), pp.729737. 10.1007/s13592-013-0219-4 . hal-01201340

\section{HAL Id: hal-01201340 \\ https://hal.science/hal-01201340}

Submitted on 17 Sep 2015

HAL is a multi-disciplinary open access archive for the deposit and dissemination of scientific research documents, whether they are published or not. The documents may come from teaching and research institutions in France or abroad, or from public or private research centers.
L'archive ouverte pluridisciplinaire HAL, est destinée au dépôt et à la diffusion de documents scientifiques de niveau recherche, publiés ou non, émanant des établissements d'enseignement et de recherche français ou étrangers, des laboratoires publics ou privés. 


\title{
Nest management increases pollinator density in passion fruit orchards
}

\author{
Camila N. Jungueira ${ }^{1}$, Marcela Yamamoto $^{2}$, Paulo E. Oliveira ${ }^{1}$, \\ Katja Hogendoorn ${ }^{3}$, Solange C. Augusto ${ }^{1}$ \\ ${ }^{1}$ Universidade Federal de Uberlândia, Campus Umuarama-Bloco 2D, CEP: 38400-902 Uberlândia, Minas Gerais, Brazil \\ ${ }^{2}$ Universidade Estadual de Goiás, Unidade Universitária de Quirinópolis, Avenida Brasil Quadra 03 Lote 01 \\ Conjunto Hélio Leão III, CEP: 75860-000 Quirinópolis, Goiás, Brazil \\ ${ }^{3}$ School of agriculture, Food and Wine, University of Adelaide, SA 5005 Adelaide, Australia
}

Received 7 March 2013 - Revised 12 June 2013 - Accepted 26 June 2013

\begin{abstract}
The yields of yellow passion fruit are vulnerable to pollinator decline because the crop is strictly self-incompatible. Nectar foraging carpenter bees are the main pollinators of this crop, whereas honeybees and stingless bees take pollen and nectar without pollination, and can be classified as "thieves". In many cropping areas, the density of effective pollinators is very low and precludes optimal yield. We investigated, over a period of 6 months, whether the provision of unoccupied and occupied carpenter bee nests could lead to (a) an increase in crop visitation by carpenter bees and (b) a decrease in visitation by thieves. We found that introduction of occupied nests can influence visitation by both carpenter bees and thieves in the expected ways, while the sole provision of unoccupied nests did not achieve this. Our study can be regarded as an important step for increasing pollinators' population in yellow passion fruit orchards using trap-nests as nesting substrate.
\end{abstract}

carpenter bees / pollination / Xylocopa / trap-nest

\section{INTRODUCTION}

Bees are recognized as the main pollinators of many native and cultivated species due to the fact that adults and offspring completely rely on pollen and nectar as food sources and because they often show floral constancy, i.e., during one collection trip, individuals tend to collect nectar or pollen from the same plant species (Rasmussen et al. 2010). The increase of productivity in several crops such as sunflower (Helianthus annuus L., Greenleaf and Kremen 2006), West Indian cherry (Malpighia emarginata DC, Vilhena et al. 2012),

Corresponding author: S.C. Augusto, scaugusto@umuarama.ufu.br Manuscript editor: Klaus Hartfelder yellow passion fruit (Passiflora edulis f. flavicarpa Degener, Yamamoto et al. 2012), alfalfa, blueberry and cranberry (Parker et al. 1987, Delaplane and Mayer 2000) is related to abundance and diversity of native bee communities.

Sustainable pollination service in crop areas depends on pollinators' populations and their conservation, which can be achieved in two ways. Firstly, areas of natural vegetation that harbor basic requirements for bees, such as food resources, nesting substrates, and material for nest building (Gathmann and Tscharntke 2002), can be preserved and protected. For example, in coffee plantations, fragments of natural vegetation enhance pollinator activity and increase productivity by $20 \%$ (Ricketts 2004; Ricketts et al. 2004). Secondly, the pollinators' populations can be 
managed, which includes introduction of bees and supplies of nest substrate in crop areas (Bosch and Kemp 2001).

Yellow passion fruit production relies on crosspollination and depends on density and even on the diversity of pollinators, which have declined in recent years (Rêgo et al. 2000; Camillo 2003; Yamamoto et al. 2012). Solitary and facultative social bees of the genus Xylocopa, the carpenter bees, are the effective pollinators of this crop because they present appropriate size and foraging behavior (Corbet and Willmer 1980; Camillo 2003). Neither honey bees (Apis mellifera) nor social stingless bees are effective pollinators (Corbet and Willmer 1980), due to their small size, they take nectar without achieving pollen transfer (Sazima and Sazima 1989; Siqueira et al. 2009). So that from here on, we refer to such bees as "thieves" (Camillo 2003).

Brazil is one of the largest world producers of yellow passion fruit with a production of approximately 664,000 tons (Agrianual Anuário Estatístico da Agricultura Brasileira 2011). However, the country's production does not meet agro-industrial market demand, requiring pulp imports from other countries to supply the national juice industry (Ferraz and Lot 2007). As an alternative to the low pollination rates in crop areas, intensive hand pollination is used. Although this is an effective method, it causes a $12 \%$ increase in production costs (Agrianual Anuário Estatístico da Agricultura Brasileira 2011).

A cheaper way to increase productivity of yellow passion fruit can be achieved through the management of carpenter bees. Most of the species excavate nests in dry plant tissues, such as dead trees or logs, hollow stems, also the use trap-nests made of bamboo canes (Camillo 2003). Xylocopa (Neoxylocopa) frontalis (Olivier 1789) and Xylocopa (Neoxylocopa) grisescens Lepeletier, 1841 , also known as "carpenter bees," are considered to be suitable for management in crop areas in Central Brazil, because they are easily reared in trapnests (Oliveira-Filho and Freitas 2003; Pereira and Garófalo 2010; Chaves-Alves et al. 2011). However, it has not been investigated whether introductions of carpenter bees actually lead to increased presence on the crop. Additionally, to optimize the pollination, it is necessary measures to control the thieves' densities, which may also improve production. This could be especially important for A. mellifera, which has a major negative impact on fruit set due to the fact that, besides nectar, this species collects pollen, which is likely to reduce the pollen loads carried by carpenter bees (Camillo 2003).

In order to define procedures that can be utilized by growers of passion fruit to improve the productivity of their crops, we evaluate the effect of nest management of $X$. frontalis and $X$. grisescens on the density of carpenter bees in crop areas located in southeastern Brazil. More specifically, we intend to verify the following: (a) whether the introduction of carpenter bees nests in passion fruit crops is a viable procedure to promote population increment and (b) whether the increase in carpenter bee numbers in the crop area and consequent increase in visitation rate to yellow passion fruit flowers cause a decrease in visitation by the thieves.

\section{MATERIAL AND METHODS}

\subsection{Study sites}

The studies were conducted in six commercial yellow passion fruit orchards with cultivated area ranging from 1.5 to 4.5 ha, around Araguari in Triângulo Mineiro region, state of Minas Gerais, southeastern Brazil, with distances among them varying from 1.9 to $30 \mathrm{~km}$ (Table I). The study areas were separated in control and experimental orchards, according to preliminary assessments of the quality of natural pollination (Table I). These assessments were done by marking 70 open, randomly chosen flowers in two $50 \mathrm{~m}$ transects, established along growing lines.

The study was carried out during the flowering period of yellow passion fruit between November 2010 and June 2011. The climate is tropical and characterized by two well defined seasons, a dry season (April-September) and a rainy season (October-March; Rosa et al. 1991).

\subsection{Procedures}

\subsubsection{Carpenter bee management}

We used two species of carpenter bees: $X$. frontalis and $X$. grisescens. Both species are suitable for manage- 
Table I. Characterization of the study areas located in Araguari, MG. Their geographical coordinates, size in hectares (ha), fruit set percentage by natural pollination (NP), and distance between areas in kilometers $(\mathrm{km})$ are provided.

\begin{tabular}{|c|c|c|c|c|c|c|c|c|c|}
\hline \multirow[t]{2}{*}{ Areas } & \multirow[t]{2}{*}{ Coordinates } & \multirow[t]{2}{*}{ Size (ha) } & \multirow[t]{2}{*}{ NP $(\%)$} & \multicolumn{6}{|c|}{ Distance $(\mathrm{km})$} \\
\hline & & & & 1 & 2 & 3 & 4 & 5 & 6 \\
\hline 1 & $18^{\circ} 36^{\prime} 15.69^{\prime \prime} \mathrm{S} / 48^{\circ} 15^{\prime} 25.34^{\prime \prime} \mathrm{W}$ & 3.0 & 4.2 & - & 6.2 & 11 & 19.2 & 11 & 5.5 \\
\hline 2 & $18^{\circ} 33^{\prime} 4.92^{\prime \prime} \mathrm{S} / 48^{\circ} 17^{\prime} 37.26^{\prime \prime} \mathrm{W}$ & 2.0 & 10 & - & - & 8.3 & 14 & 17.2 & 1.9 \\
\hline 3 & $18^{\circ} 32^{\prime} 9.50^{\prime \prime} \mathrm{S} / 48^{\circ} 17^{\prime} 18.50^{\prime \prime} \mathrm{W}$ & 4.0 & 8.3 & - & - & - & 10 & 21.1 & 7 \\
\hline 4 & $18^{\circ} 32^{\prime} 55.04^{\prime \prime} \mathrm{S} / 48^{\circ} 20^{\prime} 40.68^{\prime \prime} \mathrm{W}$ & 4.5 & 17.7 & - & - & - & - & 30 & 14 \\
\hline 5 & $18^{\circ} 32^{\prime} 55.27^{\prime \prime} \mathrm{S} / 48^{\circ} 26^{\prime} 59.73^{\prime \prime} \mathrm{W}$ & 1.5 & 14.7 & - & - & - & - & - & 16.3 \\
\hline 6 & $18^{\circ} 34^{\prime} 55.70^{\prime \prime} \mathrm{S} / 48^{\circ} 9^{\prime} 57.89^{\prime \prime} \mathrm{W}$ & 1.5 & 49.1 & - & - & - & - & - & - \\
\hline
\end{tabular}

ment in crop areas in Central Brazil because they are easily reared in trap-nests. They also exhibit similar size, foraging, and nesting behavior (Oliveira-Filho and Freitas 2003; Pereira and Garófalo 2010; Chaves-Alves et al. 2011). Furthermore, they showed similar effectiveness in transferring established nests between areas (Junqueira et al. 2012).

To assess the effect of the transfers of nests containing carpenter bees on the population density in the crop, the study sites were sorted in ascending order according to the percentage of natural pollination of each area. The introduction of occupied nests was performed in three orchards with relatively low natural pollination, referred to as experimental areas (areas 1,3, and 5); while in three control areas (areas 2, 4, and 6), no occupied nests were introduced. Unfortunately, halfway through the study, the farmer in area 2 decided to remove the orchard. Therefore, only the data about nest substrate supply is available for this area.

\subsubsection{Carpenter bees nest introduction and nest substrate supply in experimental and control areas}

A bee shelter made of wood rafters and a yellow plastic canvas cover of $1.8 \mathrm{~m}$ high and $1.0 \mathrm{~m}$ long was constructed in each of the experimental and control areas. Each bee shelter contained 48 trap-nests made of bamboo canes that were closed at one end by the node. They had a length of approximately $25 \mathrm{~cm}$, and an inner diameter ranging from 1.8 to $2.2 \mathrm{~cm}$. This diameter range is consistent with the range of highest occupation of Xylocopa species in this kind of trap-nests (Pereira and Garófalo 2010). The trap-nests were placed in hollow bricks that were arranged horizontally on shelves. Access by ants was prevented by applying Tanglefoot ${ }^{\circledR}$ to the supports of the bee shelters. Established nests of $X$. frontalis and $X$. grisescens were introduced into the experimental areas 3 months after the nest substrate was supplied in the bee shelter. The introduced nests were sourced from a breeding area located around $60 \mathrm{~km}$ from the farms.

To determine the optimal number of bees to be introduced into each experimental study area, we used the following assumptions: (a) the introduction of 25 nests of Xylocopa spp. per hectare resulted in a $700 \%$ increase in natural pollination in São Paulo (Camillo 2003) and (b) approximately $50 \%$ of introduced females remained in their nests after transference (Junqueira et al. 2012). Therefore, we introduced four nests per hectare expecting to get at least a fraction of the pollination increase obtained in São Paulo.

During the yellow passion fruit flowering period (March 2011), 29 nests of $X$. frontalis and 7 nests $X$. grisescens were introduced into three experimental areas: area 1, 15 nests of $X$. frontalis and 3 nests of $X$. grisescens; area 2, 8 nests of $X$. frontalis and 4 nests of $X$. grisescens; area 3, 6 nests of $X$. frontalis. These nests contained one adult female with or without brood cells. The number of brood cells ranged from 1 to 4 , with an average of 1.7 brood cells per introduced nest. Although females remain more often in nests containing brood cell (cbc) than in nests without brood cells (wbc; Junqueira et al. 2012), we introduced both kinds of nests, as the 
availability of numbers of nests with brood cells in the breeding area did not cover the numbers of nests required. The number of cbc/wbc nests in areas 1, 3, and 5 were, respectively, $6 \mathrm{cbc} / 12 \mathrm{wbc}, 4 \mathrm{cbc} / 8 \mathrm{wbc}$, and $3 \mathrm{cbc} / 3 \mathrm{wbc}$.

The bees present in the introduced nests and bees from the surrounding area that started using the trap-nests in the bee shelter were individually marked with numbered tags (Yamamoto et al. unpubl. data), which allowed monitoring introduced females and observing nest switching and new nest foundations. The number of occupied and newly founded nests was assessed monthly over a period of 6 months after the introduction of the nests.

\subsubsection{Effect of introduction on flower visitation by carpenter bees and by thieves}

The flower visitation by carpenter bees and by thieves (A. mellifera and stingless bee species, mainly Trigona species) was assessed in experimental areas before the introduction of the nests, in January $2011\left(T_{0}\right)$, and after nest introductions, in April $2011\left(T_{1}\right)$; in control areas, flower visitation was assessed in the same periods ( $T_{0}$ and $T_{1}$ ). Flower visitation was measured as the number of visits per number of open flowers per observation time (Winfree et al. 2008), using a transect census method (Dafni et al. 2005). Two $50 \mathrm{~m}$ transects, spaced $2.5 \mathrm{~m}$ among them, were established along growing lines in each study area. Each transect was walked for $10 \mathrm{~min}$, between 1230 hours and 1730 hours, at hourly intervals with a sampling effort of $4 \mathrm{~h}$ per study area. These censuses were conducted on sunny and warm days, which presented both the highest number of open flowers and the activity of bee species (Yamamoto et al. unpubl. data). During the census, the number of open flowers and the number of carpenter bees and thieves were recorded. We compared the number of open flowers during the censuses in order to confirm if this parameter was similar in all study areas during $T_{0}$ and $T_{1}$.

\subsection{Data analysis}

Statistical analysis was performed using the statistical program SYSTAT 10.2C (2002; Zar 1999). For data analysis, we considered as samples the days on which we performed the transect census and pollination treatments $\left(T_{0}\right.$ and $\left.T_{1}\right)$. Data normality was tested using Kolmogorov-Smirnov (Lilliefors; $P>0.05$ ). Chi-square test was performed to compare the effectiveness of nest transfer between areas, and matched pairs $t$ tests were used to compare visitation rate of pollinators and thieves and the number of open flowers in $T_{0}$ and $T_{1}$.

\section{RESULTS}

\subsection{Effectiveness of nest introductions}

The percentage of introduced females that remained in their nests ranged from $38.7 \%$ to $66.7 \%$ (Table II). Although the permanence in area 1 was lower than in areas 3 and 5, this difference was not significant $\left(\chi^{2}=2.79, P=\right.$ $0.25, d f=2)$. A higher percentage of females remained in nests with brood cells than without brood cells (Table II). Combining the number of introduced nests in which the females remained and the new nests that were founded in areas 1 , 3 , and 5 , the total increase in numbers of nests after 6 months was $42.8 \%, 37.5 \%$, and $100 \%$. No new nests were founded in the experimental areas before the introduction of occupied nests. No nests were founded in the control areas $(2,4$, and 6).

\subsection{Nest management effect on visitation rate of carpenter bees and thieves}

After nest introductions, flower visitation by $X$. frontalis and $X$. grisescens increased significantly in the experimental areas 3 and 5 (area 3, $t_{0.05(2) 4}=2.74, P=0.05$; area $5, t_{0.05(2) 4}=4.11, P=$ 0.001 ; Figure 1$)$. In the experimental area 1 , the increase of the visitation rate was not significant $\left(t_{0.05(2) 4}=-1.46, P=0.21\right)$.

Flower visitation by thieves significantly decreased after carpenter bees nest introduction in experimental areas 3 and 5 (area $3, t_{0.05(2) 4}=-2.74$, $P=0.05$; area $5, t_{0.05(2) 4}=7.90, P=0.001$; Figure 1$)$. In experimental area 1 , the decrease in flower visitation by thieves was not significant $\left(t_{0.05(2) 4}=\right.$ $1.86, P=0.12$ ).

In control area 4 , we did not observe any individuals of $X$. frontalis and $X$. grisescens during either $T_{0}$ or $T_{1}$. In control area 6 , there was no significant difference between $T_{0}$ and $T_{1}$ in the flower visitation by carpenter bees (area $\left.6, t_{0.05(2) 4}=0.59, P=0.59\right)$. Furthermore, the 
Table II. Permanence percentage of $X$. frontalis and $X$. grisescens ca. 30 days after nest introductions to yellow passion fruit orchards $(n=36)$. Data of permanence with or without brood cells in the nests $(c b c$ containing brood cell, $w b c$ without brood cells), total of nest introduction $\left(\mathrm{T}_{\text {intro }}\right)$, total of female permanence $\left(\mathrm{T}_{\text {perm }}\right)$, new nest foundation, and percentage of nest increase.

\begin{tabular}{lccccc}
\hline & \multicolumn{2}{c}{ Female's permanence } & New nests foundation & Nest increase (\%) \\
\cline { 2 - 4 } & $\mathrm{cbc}(\%)$ & wbc (\%) & $\mathrm{T}_{\text {intro }} / \mathrm{T}_{\text {perm }}(\%)$ & & \\
\hline Area 1 & $5(83)$ & $2(17)$ & $18 / 7(39)$ & 3 & 43 \\
Area 3 & $3(75)$ & $5(62.5)$ & $12 / 8(67)$ & 3 & 37.5 \\
Area 5 & $3(100)$ & $1(33)$ & $6 / 4(67)$ & 4 & 100 \\
\hline
\end{tabular}

flower visitation by thieves did not change significantly during the observation period in either control area (area $4, t_{0.05(2) 4}=1.5, P=0.20$; area $6, t_{0.05(2) 4}=1.16, P=0.31$; Figure 1$)$.

In the orchards evaluated, the number of flower/transect in the control and experimental areas ranged from 79 to 164 and 186 to 255 , respectively. There was no significant difference on the amount of open flowers between $T_{0}$ and $T_{1}$ (area $1, t_{0.05(2) 12}=-1.08, P=0.30$; area 3 , $t_{0.05(2) 12}=1.44, P=0.17$ and area $5, t_{0.05(2) 12}=$ $1.25, P=0.23$; area $4, t_{0.05(2) 12}=-0.33, P=0.74$ and area $\left.6, t_{0.05(2) 12}=7.01, P=0.10\right)$.

\section{DISCUSSION}

The nest introduction of $X$. frontalis and $X$. grisescens in yellow passion fruit orchards was successful as more than $50 \%$ of the introduced females remained in their nests after the transfers and new nests were founded after introduction. A permanence of $50 \%$ was also found in other studies that investigated carpenter bee management (Freitas and Oliveira-Filho 2001; Junqueira et al. 2012). The higher percentage of permanence (around $80 \%$ ) displayed by females with brood cells was also observed and discussed by Junqueira et al. (2012) in a long-term study realized in an agroecosystem.

Our results regarding the successful nest transfer into crop areas can be attributed, among other aspects, to the fact that these Xylocopa species use a wide range of food sources (Keasar 2010), and to their ability to forage over a long distance (Kapil and Dhaliwal 1969). Yellow passion fruit is only a nectar source for $X$. frontalis and $X$. grisescens and pollen needs are to be obtained from areas surrounding yellow passion fruit orchards, which often contain small fragments of remnant native vegetation with limited food resources (Klink and Machado 2005; Silva et al. 2012) or others crops, as occurred in the studied areas.

New nest foundation was only observed in experimental areas after introduction of the nests, and never in the control areas. Therefore, the successful introduction of an initial population of carpenter bees in the bee shelters, combined with a supply of nest substrate, is crucial to build up Xylocopa bees' population over a period of time like flowering season of yellow passion fruit.

We did not observe any $X$. frontalis and $X$. grisescens during the first sample in three out of six orchards. In the other areas, there was a low visitation rate of these species, probably due to low population densities of these bees. A low density of carpenter bees in yellow passion fruit orchards is often observed in Brazil (Freitas and OliveiraFilho 2001; Camillo 2003). Although the proportion of natural vegetation surrounding crops areas, which is known to influence native bee densities (Greenleaf and Kremen 2006), was not investigated, the yellow passion fruit orchards used in this study are located in the Cerrado, a Brazilian savanna with a recent history of fragmentation due to farmland expansion (Klink and Machado 2005). It is possible that the low population densities of carpenter bees in these areas are associated with a lack of natural vegetation cover, 

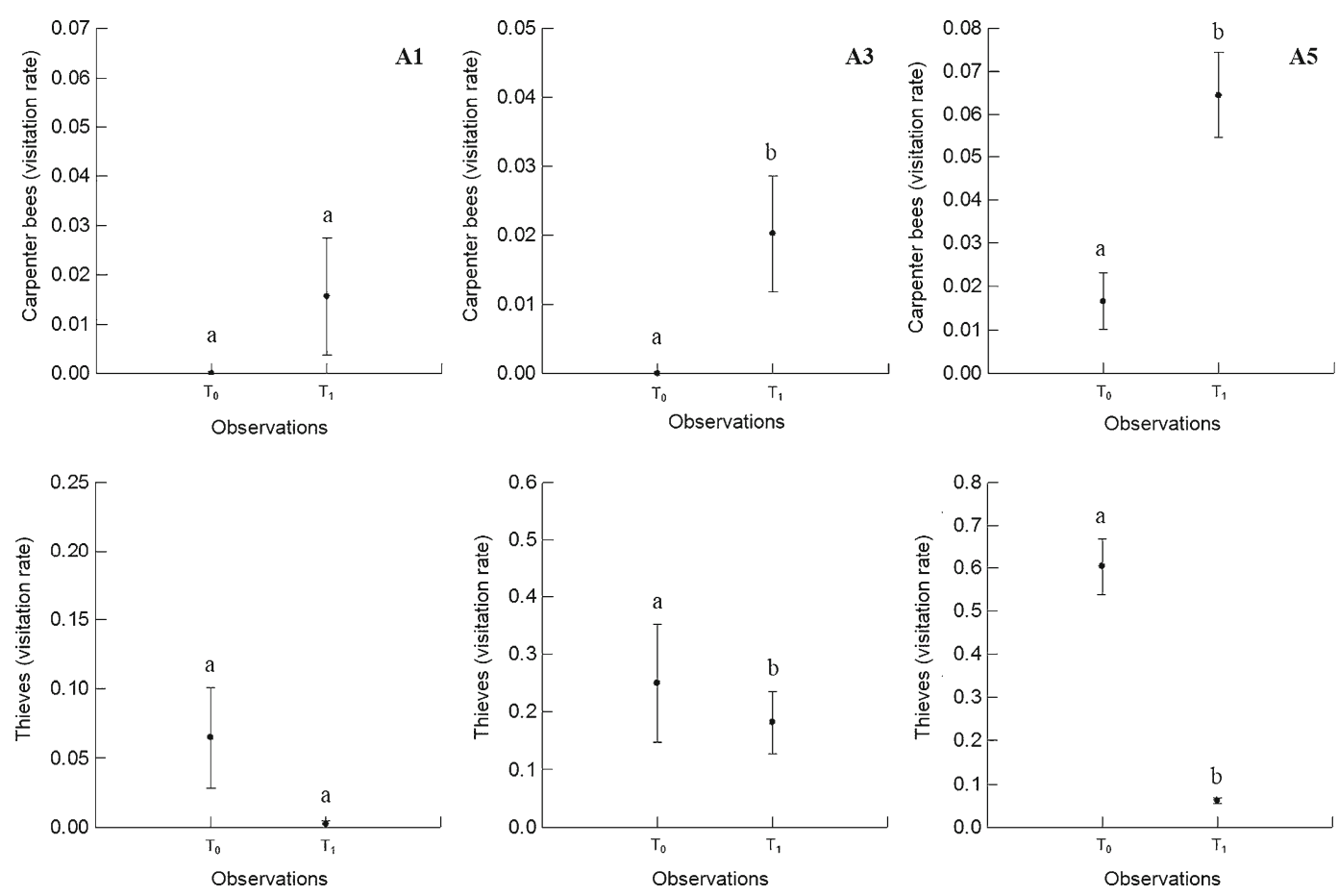

Figure 1. Average ( $\pm \mathrm{SE})$ of flower visitation by carpenter bees $(X$. frontalis and $X$. grisescens) and thieves $(A$. mellifera and stingless bee species) before $\left(\mathrm{T}_{0}\right)$ and after $\left(\mathrm{T}_{1}\right)$ the introduction of nests in three experimental areas (A1, A3, and A5). Superscript letters indicate equality or difference of means between samples.

as observed for other crops (Kremen et al. 2002; Ricketts 2004). Nevertheless, the females' permanence success and the foundation of new nests due to the supply of nesting substrate, indicates that population of carpenter bees can be, at least temporarily, increased in such areas. It would be interesting to see if sustained renewal of nesting substrate can lead to a more permanent increase.

Nest management of $X$. frontalis and $X$. grisescens resulted in significant increase in pollinators' visitation rate in two yellow passion fruit orchards (experimental area 3 and 5). The introduction of four nests of $X$. frontalis and $X$. grisescens per hectare, together with nest substrate led to significant changes in visitation rates, which indicate that these methods contribute to progress in the sustainable use of pollinators (Keasar 2010).

Visitation by pollinators is influenced by the density of flowers, as their visits depends on the attractants and rewards available (Eckhart 1992; Conner and Rush 1996). In our study, the density of flowers did not vary between the censuses performed in $T_{0}$ and $T_{1}$, which reinforces the conclusion that the increase of carpenter bees density on the flowers was the result of the introduction of occupied nests.

Increase in the density of solitary bees has also been achieved using nest boxes for $X$. frontalis and Centris analis in crop areas located in northeastern Brazil (Freitas and Oliveira-Filho 2003; Magalhães and Freitas 2013). Furthermore, in the United States, management of solitary species of the family Megachilidae using different trap-nests has lead to increased densities in apples, almonds, and alfalfa crops (Torchio 1984; Bosch and Kemp 2001, 2002). The success of these studies is associated with the introduction of the adequate amount of pollinators' nests to achieve significant increases in natural 
pollination level. However, quantification of the number of bees and nests needed remains a challenge in crop pollination studies and further studies are required (Magalhães and Freitas 2013).

In one of the three areas (experimental area 1), nest introductions did not lead to either an increase in bee densities on the crop, or a decrease in thieves. This area initially had the highest pollinator deficit, as indicated by the low natural pollination level. After the introduction of occupied nests, this area also had a lower level of permanence than the other two experimental areas. Together, these results may suggest that the area surrounding the crop were less suitable for sustaining pollinators, either due to a lack of forage (pollen) or to the use of insecticides. Thus, the benefits of nest introduction may depend both on pollination levels present and the ability of the surrounding area to sustain a population of introduced bees. It would be interesting to see whether, in addition to the introduction of occupied nests, restoration of native vegetation or companion planting of pollen sources for carpenter bees, such as tomato (Solanum lycopersicum L.) or Senna species, which provide pollen that cannot be accessed by honeybees (King and Buchmann 2003), could achieve an increase in pollination densities in such areas (Silva et al. 2010; Giannini et al. 2013).

Thieves have a negative effect on the production of yellow passion fruit because they damage the flowers, and being social species, they can quickly reduce the pollen/nectar available to solitary pollinators (Sazima and Sazima 1989). Furthermore, it has been shown that the presence of thieves can reduce the number and duration of visits by pollinators (Sazima and Sazima 1989). In our study, the visitation rate of thieves was higher than that of pollinators in all observation periods. This is associated with the social habit of $A$. mellifer $a$ and the stingless bee species considered in this study, which presents numerous large colonies and group foraging behavior (Roubik 1989; Silveira et al. 2002). The observed reduction of thieves' visitation rate in areas that showed an increase of pollinators' visitation rate may be related to increased nectar competition. Carpenter bee species are large and require a high nectar intake, which may either decrease the amount of nectar available (Gathmann and Tscharntke 2002) or increase the variation in the nectar standing crop, resulting in decreased visitation by thieves (Keasar et al. 2008).

Previous studies in yellow passion fruit orchards indicate that the higher density of thieves in the initial (September-November) and late flowering (May-June) period than in the period in-between, is probably related to food resource availability in the areas surrounding crop during this period (Benevides et al. 2009). The sampling period of this study was conducted at peak flowering (January-April), thus reducing the time dependent effect of flowering density on the thieves' visitation rates. This is demonstrated by the lack of difference in the density of flowers and thieves between the sampling dates in the control areas. Therefore, it is possible that the increased visitation rate of $X$. frontalis and $X$. grisescens presented a negative effect on thieves' visitation rate in our experimental areas.

Our study can be regarded as an important step for increasing the pollinator population in yellow passion fruit orchards using trap-nests as nesting substrate. Nest introduction of $X$. frontalis and $X$. grisescens and the supply of additional nest substrate are efficient management techniques, since it was possible to maintain and enhance carpenter bee populations in crop areas. This augmentation had a positive effect on the flower visitation rates of the pollinators combined with a negative effect on the visitation rates of thieves, thus enhancing sustainable pollination services. Future investigations are needed to assess the effect of carpenter bee introductions on the yield and the quality of yellow passion fruit, and on the importance the surrounding vegetation for potential to sustain the higher density of these efficient pollinators. This will allow fine-tuning the densities of nests required in the crop areas and will lead to the design of successful management systems.

\section{ACKNOWLEDGMENTS}

This study was supported by grants from Fundação de Amparo à Pesquisa do Estado de Minas Gerais (FAPEMIG), Coordenadoria de Aperfeiçoamento de Pessoal de Nível Superior (CAPES), through Programa 
Nacional de Cooperação Acadêmica (PROCAD), and Conselho Nacional de Desenvolvimento Científico e Tecnológico $(\mathrm{CNPq})$. We are grateful to yellow passion fruit producers from Araguari-MG for allowing our field work. S.C. Augusto received research fellowship from Conselho Nacional de Desenvolvimento Científico e Tecnológico (CNPq; proc. 307222/2012-8), M. Yamamoto had FAPEMIG grants (CRA-PDJ 0187-09 and CRA-BPD 0132-11), and C. N. Junqueira received a fellowship from CAPES.

La mise en place de sites de nidification dans des vergers de fruits de la passion augmente la densité des pollinisateurs

\section{Abeille charpentière / pollinisation / Xylocopa / Brésil / nid-piège}

Nisthilfgenangebot erhöht die Bestäuberdichte in Passionsfruchtplantagen

\section{Holzbienen / Bestäubung / Xylocopa / Nistfallen}

\section{REFERENCES}

Agrianual Anuário Estatístico da Agricultura Brasileira. (2011) FNP Consultoria e Comércio, São Paulo, Brasil

Benevides, C. R., Gaglianone, M. C., Hoffmann. M. (2009) Visitantes florais do maracujá-amarelo (Passiflora edulis f. flavicarpa Deg., Passifloraceae) em áreas de cultivo com diferentes proximidades a fragmentos florestais na região Norte Fluminense, RJ. Rev. Bras. de Entomol. 53, 415-421

Bosch, J., Kemp, W.P. (2001) How to manage the blue orchard bee, Osmia lignaria, as an orchard pollinator. Sustainable Agriculture Network, Washington, DC

Bosch, J., Kemp, W.P. (2002) Developing and establishing bee species as crop pollinators: the example of Osmia spp. (Hymenoptera: Megachilidae) and fruit trees. Bull. Entomol. 92, 3-16

Camillo, E. (2003) Polinização de maracujá. Holos Editora, Ribeirão Preto, SP

Chaves-Alves, T.M., Junqueira, C.N., Rabelo, L.S., Oliveira, P.E.A.M., Augusto, S.C. (2011) Recursos ecológicos utilizados por las especies de Xylocopa (Hymenoptera, Apidae) en el área urbana. Rev. Colomb. Entomol. 37, 313-317

Corbet, S.A., Willmer, P.G. (1980) Pollination of the yellow passion fruit: nectar, pollen and carpenter bees. J. Agric. Sci. 95, 655-666

Conner, J.K., Rush, S. (1996) Effects of Flower Size and Number on Pollinator Visitation to Wild Radish, Raphanus raphanistrum. Oecologia 105, 509-516
Dafni, A., Kevan, P.G., Husband, B.C. (2005) Practical Pollination Biology. Enviroquest, Cambridge

Delaplane, K.S., Mayer, D.F. (2000) Crop Pollination by bees. Entomol. Exp. Appl. 99, 127-129

Eckhart, V.M. (1992) Spatio-temporal variation in abundance and variation in foraging behavior of the pollinators of gynodioecious Phacelia linearis (Hydrophyllaceae). Oikos 64, 573-586

Ferraz, J.V., Lot, L. (2007) Fruta para consumo in natura tem boas perspectivas de renda, in Agrianual Anuário Estatístico da Agricultura Brasileira. FNP Consultoria e Comércio, São Paulo, Brasil

Freitas, B.M., Oliveira-Filho, J.H. (2001) Criação racional de mamangavas para polinização em áreas agrícolas. Banco do Nordeste, Fortaleza, Brazil

Freitas, B.M., Oliveira-Filho, J.H. (2003) Ninhos racionais para mamangava (Xylocopa frontalis) na polinização do maracujá-amarelo (Passiflora edulis). Cienc. Rural. 33, 1135-1139

Gathmann, A., Tscharntke, T. (2002) Foraging ranges of solitary bees. J. Anim. Ecol. 71, 757-764

Giannini, T.C., Acosta, A.L., Silva, C.I., Oliveira, P.E.A.M., Imperatriz-Fonseca, V.L., Saraiva, A.M. (2013) Identifying the areas to preserve passion fruit pollination service in Brazilian Tropical Savannas under climate change. Agric. Ecosyst. Environ. 171, $39-46$

Greenleaf, S.S., Kremen, C. (2006) Wild bees enhance honey bees' pollination of hybrid sunflower. P. Natl. Acad. Sci. USA 103, 13890-13895

Junqueira, C.N., Hogendoorn, K., Augusto, S.C. (2012) The Use of Trap-Nests to Manage Carpenter Bees (Hymenoptera: Apidae: Xylocopini), Pollinators of Passion Fruit (Passifloraceae: Passiflora edulis $\mathrm{f}$. flavicarpa). Ann. Entomol. Soc. Am. 105(6), 884889

Kapil, R.P., Dhaliwal, J.S. (1969) Biology of Xylocopa species. II. Field activities, flight range and trials on transportation of nests. J. Res. Punjab. Agric. Univ. 6, 262-271

Keasar, T. (2010) Large Carpenter Bees as Agricultural Pollinators. Psyche 2010, 1-7

Keasar, T., Sadeh, A., Shmida, A. (2008) Variability in nectar production and standing crop, and their relation to pollinator visits in a Mediterranean shrub. Arthropod Plant Interact. 2, 117-123

King, M.J., Buchmann, S.L. (2003) Floral sonication by bees: mesosomal vibration by Bombus and Xylocopa, but not Apis (Hymenoptera: Apidae), ejects pollen from poricidal anthers. J. Kansas Entomol. Soc. 76, 295-305

Klink, C.A., Machado, R.B. (2005) Conservation of the Brazilian Cerrado. Conserv. Biol. 19, 707-713

Kremen, C., Williams, N.M., Thorp, R.W. (2002) Crop pollination from native bees at risk from agricultural intensification. Proc. Natl. Acad. Sci. USA 99, 16812-16816 
Magalhães, C.B., Freitas, B.M. (2013) Introducing nests of the oil-collecting bee Centris analis (Hymenoptera: Apidae: Centridini) for pollination of acerola (Malpighia emarginata) increases yield. Apidologie 44, 234-239

Oliveira-Filho, J.H., Freitas, B.M. (2003) Colonização e biologia reprodutiva de (Xylocopa frontalis) em um modelo de ninho racional. Cienc. Rural. 33, 693-697

Parker, F.D., Batra, S.W.T., Tepedino, V.J. (1987) New pollinators for our crops. Agr. Zool. Rev. 2, 279-303

Pereira, M., Garófalo, C.A. (2010) Biologia da nidificação de Xylocopa frontalis e Xylocopa grisescens (Hymenoptera, Apidae, Xylocopini) em ninhos-armadilha. Oecol. Aust. 14, 193-209

Rasmussen, C., Nieh, J.C., Biesmeijer, J.C. (2010) Foraging biology of neglected bee pollinators. Psyche 2010, 1-2

Rêgo, M.M., Rêgo, E.R., Bruckner, C.H., Da Silva, E.A.M., Finger, F.L., Pereira, K.J.C. (2000) Pollen tube behavior in yellow passion fruit following compatible and incompatible crosses. Theor. Appl. Genet. 10, 685-689

Ricketts, H.T. (2004) Tropical forest fragments enhance pollinators activity in nearby coffee crops. Conserv. Biol. 18, 1262-1271

Ricketts, H.T., Daily, G.C., Ehrlich, P.R., Michener, C.D. (2004) Economic value of tropical forest to coffee production. P. Natl. Acad. Sci. USA 101, 12579-12582

Rosa, R., Lima, S.C.C., Assunção, W.L. (1991) Abordagem preliminar das condições climáticas de Uberlândia (MG). S \& N. 3, 91-108

Roubik, D.W. (1989) Ecology and natural history of tropical bees. Cambridge University Press, Cambridge

Sazima, I., Sazima, M. (1989) Mamangavas e irapuás (Hymenoptera, Apoidea): visitas, interações e conseqüências para polinização do maracujá (Passifloraceae). Rev. Bras. Entomol. 33, 109-118

Silva, C.I., Ballesteros, P.L.O., Palmero, M.A., Bauermann, S.G., Evaldit, A.C.P., Oliveira, P.E.A.M. (2010) Catálogo Polínico-Palinologia aplicada em estudos de conservação de abelhas do gênero Xylocopa. EDUFU, Uberlândia, Brazil

Silva, C.I., Bordon, N.G., Rocha Filho, L.C., Garófalo, C.A. (2012) The importance of plant diversity in maintaining the pollinator bee, Eulaema nigrita (Hymenoptera: Apidae) in sweet passion fruit fields. Rev. Biol. Trop. 60(4), 1553-1565

Silveira, F.A., Mello, G.A.R., Almeida, E.A.B. (2002) Abelhas brasileiras. Sistemática e Identificação, Fundação Araucária, Belo Horizonte, Minas Gerais, Brazil

Siqueira, K.M.M., Kiill, L.H.P., Martins, C.F.M., Lemos, I.B.S., Monteiro, P., de Feitoza, E.A. (2009) Ecologia da polinização do maracujá-amarelo, na região do vale do submédio São Francisco. Rev. Bras. Frutic. 31, 1-12

Systat (2002) Systat Software Inc., version 10.2. San Jose, CA

Torchio, P.F. (1984) Field experiments with the pollinator species, Osmia lignaria propinqua Cresson (Hymenoptera: Megachilidae) in apple orchards. J. Kansas Entomol. Soc. 57, 517-521

Vilhena, A.M.G.F., Rabelo, L.S., Bastos, E.M.A., Augusto, S.C. (2012) Acerola pollinators in the savanna of Central Brazil: temporal variations in oilcollecting bee richness and a mutualistic network. Apidologie 43, 51-62

Winfree, R., Williams, N.M., Gaines, H., Ascher, J.S., Kremen, C. (2008) Wild bee pollinators provide the majority of crop visitation across land-use gradients in New Jersey and Pennsylvania. USA. J. Appl. Ecol. 45, 793-802

Yamamoto, M., Silva, C.I., Augusto, S.C., Barbosa, A.A.A., Oliveira, P.E. (2012) The role of bee diversity in pollination and fruit set of yellow passion fruit (Passiflora edulis forma flavicarpa, Passifloraceae) crop in Central Brazil. Apidologie 43, 515-526

Zar, J.H. (1999) Biostatistical analysis. Prentice Hall, Upper Saddle River, NJ 